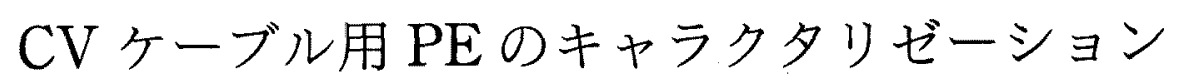

$\begin{array}{llllll}\text { 正員 丹羽 } & \text { 利 夫 } & \text { (フジクラ) } & \text { 非会員 中 司 } & \text { 徹 (フジクラ) } \\ \text { 正員 中 山 四郎 } & \text { (フジクラ) } & \text { 正 員 高 橋 } & \text { 亨 (フジクラ) } \\ \text { 非会員 小林 一 治 } & \text { (フジクラ) } & & & & \end{array}$

\title{
Characterization of Polyethylene for Power Cable Insulation
}

Toshio Niwa, Member, Shiro Nakayama, Member, Kazuharu Kobayashi, Non-member, Tohru Nakatsuka, Non-member, Tohru Takahashi, Member (Fujikura Ltd.)

The various properties of polyethylenes used for XLPE cable insulations were evaluated, and followings were cleared out. At first, as for the rheological characteristics, the molecular weight distribution is different among the polyethylenes which show the same MFR values. Secondly, as for the crosslinking characteristics, the number of several chemical functional groups in polyethylene molecules are different between that of before and after the crosslinking. And relations are observed between the crosslinking reactivity and the number of some specific double bond. Melting temperature decreases in contrast with the increase of the degree of crosslinking, which is due to the decrease of crystallinity of polyethylene. Thirdly, in terms of breakdown strengthes, they are also affected with the degree of crosslinking, especially in the high temperature regions. This is due to the increase of elastic modulus brought by the network formation with crosslinking reaction.

キーワード：ポリエチレン, 架橋ポリエチレン, MFR, 分岥, 密度, 融点, 絶緑破壞強度

\section{1.まえがき}

ポリエチレン (以下, PEと略記) を有機過酸化物 で架橋した架橋ポりエチレン（以下，XLPEと略記） が電力ケーブル用絶縁体として採用されて既に 30 年 が経過した。その間，材料自身の改良に加え，ケーブ ル製造技術の向上もあいまって，現在，XLPE絶縁 電力ケーブルは $500 \mathrm{kV}$ までの超高圧 CV ケーブルと して使用されるに至っている。

一方, 電気絶縁材料としてのPEおよびXLPEに ついては，結晶構造と電気特性の関係についての研究 例，あるいは水トリー現象解明に関連しての研究の報 告は多数なされており，微細構造の絶緑破壊特性に与 える影響，添加剂や共重合などによる改質などについ

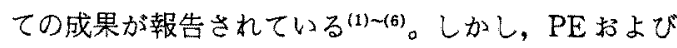
XLPEの広範な物性相互の関係についての研究報告 はほとんど見あたらず, 部分的な内容のものが散見さ
れるのみである(7)(8)。超高圧ケーブル用材料の開発を 行っていくうえでの基礎的検討として，PE京よび XLPEの種々の物性相互の関係を詳しく把握し, 物 性の生じる機構を明らかにすることは重要であると考 えられる。著者らはこうした観点に立ち，PEおよび XLPE の物性相互の関係, なかでもPEの溶融物性, 架橋反応とPE の化学構造との関係, および架橋によ る絶緑破壊特性向上について検討した。その結果, 電 気絶縁用 PE の化学構造が明らかになるとともに，化 学構造および分子量分布の溶融物性に与える影響括よ び化学構造と架橋反応の関係についても一定の関係が 判明し，新しい知見が得られた。更に，絶縁破壞特性 に与える架橋の影響を検討した結果, 架橋による高温 での絶縁破塄強度の向上が確認され，その主たる破壊 機構の推論がなされた。本研究で得られた成果は今後 の高電圧電力ケーブル用材料開発を進めていくうえで 興味深いものであると考える。 


\section{2. 実験方法}

〈2・1〉試料 高電圧 XLPE ケーブル絶緑体 用ベース PEとして，市殿されている製造条件の異な る低密度 PE（以下，LDPE と略記）のなかから， チ ニーブラ法により重合した 3 試料を抽出した。また参 考試料として, 同一装置により重合した架橋用ベース PE 6 種を選定した。それらの MFR および密度を表 1 亿示す。

以上 9 種の試料を架橋してXLPEとするには，架 橋剤として DCP (Dicumyl Peroxide) を配合し, 老 化防止剂として 4,4'-Thio-bis (3-methyl-6-t-butylphenol）を配合した混合物を $110^{\circ} \mathrm{C} に て$ 混練して得, 更に $160^{\circ} \mathrm{C} て ゙ 40$ 分加圧加熱して架橋させた。架橋後, 水冷プレスにて室温まで加圧冷却した。また，架橋さ せないべース PEについても XLPE と同様の熱履歴 を与えたものを試験に供した。

\section{〈2.2〉 物性評価方法}

（1）分子量分布 $\mathrm{PE}$ の分子量分布は GPC 法 (Gel Permeation Chromatography) により $135^{\circ} \mathrm{C} て ゙$ 測定した。

（2）架橋度 JIS C 3005に定める溶剤抽出法に より測定し，ゲル分率で表示した。

（3）赤外吸光分析 FT-IR（フーリエ変換赤 外吸光光度計）を用い，フィルム法により $\mathrm{PE,}$ XLPEの両者について赤外吸光スペクトルを測定し た。スペクトル解析に対しては吸収スペクトル強度に 応じて $0.2 \mathrm{~mm}$ または $1 \mathrm{~mm}$ 掌さの試料を用いた。赤

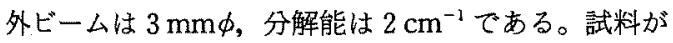
XLPEの場合, 架橋剤分解物がスペクトルに影響す るため, あらかじめ $50^{\circ} \mathrm{C} に て ， 24$ 時間， $5 \mathrm{mmHg}$ の 隇圧下で処理して分解物を取り除いて試験に供した。

上く知られている上うに, 赤外吸収スペクトルは分 子の化学構造に特有の吸収 (特性吸収) をもつ。主要

表 1 評洒試料

Table 1. Test samples.

\begin{tabular}{c|c|c|c}
\hline 区 分 & 記号 & $\begin{array}{c}\text { MFR } \\
(\mathrm{g} / 10 \mathrm{~min})\end{array}$ & $\begin{array}{c}\text { 密度 } \\
\left(\mathrm{g} / \mathrm{cm}^{3}\right)\end{array}$ \\
\hline \multirow{3}{*}{ 比梗試料 } & $A$ & 1.0 & 0.9176 \\
& $B$ & 1.2 & 0.9225 \\
& $C$ & 1.2 & 0.9210 \\
\hline \multirow{5}{*}{ 参考試料 } & $a$ & 0.85 & 0.9228 \\
& $b$ & 1.0 & 0.9185 \\
& $c$ & 1.9 & 0.9220 \\
& $d$ & 2.2 & 0.9220 \\
& $e$ & 2.4 & 0.9220 \\
& $f$ & 3.2 & 0.9220 \\
\hline
\end{tabular}

な特性吸収の帰属および試料中の化学構造の濃度を求 めるための換算係数 $\varepsilon$ は多くの文献值を参考に定め た ${ }^{(9) \sim(15)}$ 。試料中の化学構造の濃度は下式により求め た。

$n_{i}=\varepsilon_{i} A_{i} / \rho t$

ただし, $n_{i}$ : 化学基 $i$ の濃度（個 $/ 1,000 \mathrm{C}$ ), $\varepsilon_{i}$ : 化学基 $i$ の換算係数, $A_{i}$ : 化学基 $i$ の 特性吸収の吸光度, $\rho:$ 試料の密度 $\left(\mathrm{g} / \mathrm{cm}^{3}\right)$, $t:$ 試料の厚さ $(\mathrm{mm})$

PE 抢よびXLPE 赤外スペクトルの一例を図 1 に, 赤外吸収の帰属と換算係数を表 2 に示す。表中の No と図1のスペクトルに付した Noは同一の特性吸収で あることを示す。

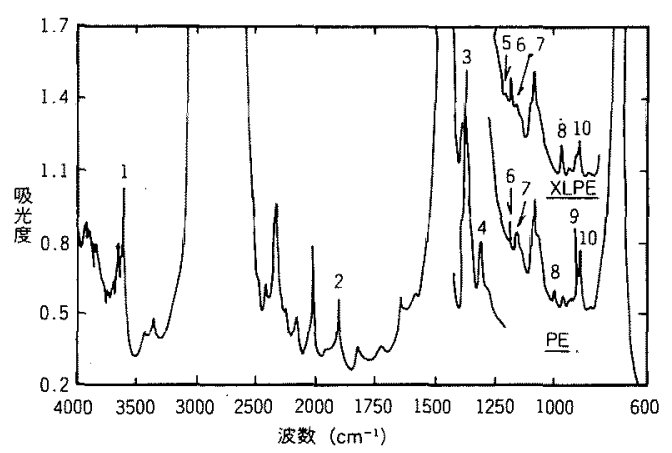

図 $1 \mathrm{PE}$ およびXLPEのIR スペクトル

Fig. 1. IR spectra of $P E$ and XLPE.

表 2 IR 吸取の帰属と換算係数 Table 2. Band characterization and concentration factor of IR spectrum.

\begin{tabular}{|c|c|c|c|}
\hline No. & $\begin{array}{c}\text { 波数 } \\
\left(\mathrm{cm}^{-1}\right)\end{array}$ & 㷌 & 換算係数 $\varepsilon$ \\
\hline 1 & 3,604 & 第3アルコール基のOHの伸縮 & 0.64 \\
\hline 2 & 1,897 & 結暐バンド & 2.1 \\
\hline 3 & 1,378 & イチル基 $\mathrm{CH}_{3}-\mathrm{C}-\mathrm{H} の$ 対标变角 & 5.3 \\
\hline 4 & 1,303 & 非昆バント & 0.41 \\
\hline 5 & \pm .200 & ジイ支ル分岐-CHz & $\begin{array}{l}20 . \\
\text { (XLPEのみ) }\end{array}$ \\
\hline 6 & 1,178 & イソプロピル基 $\mathrm{CH}_{3}>\mathrm{CH}^{-の}$ 骨格振動 & 15 . \\
\hline 7 & 1.155 & 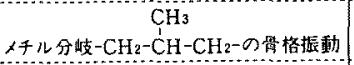 & 58. \\
\hline 8 & 966 & 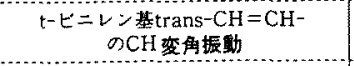 & 0.83 \\
\hline 9 & 908 & ビ二ル基 $\mathrm{CH}_{2}=\mathrm{CH}-\sigma \mathrm{CH}_{2}$ 变角振野 & 1.14 \\
\hline 10 & 890 & 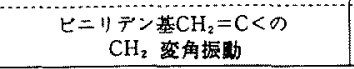 & 1.09 \\
\hline
\end{tabular}




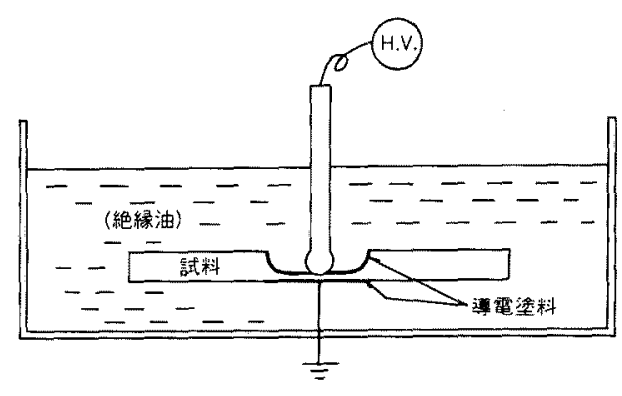

図 2 絶縁破壊強さ試験の概要

Fig. 2. Outline of dieletric strength test.

（4）MFR MFR（Melt Flow Rate）は樹脂 の溶融流動特性を示す一つの指標である。本実験では ASTM D 1238-86 に従い荷重 $2.16 \mathrm{~kg}$, 温度 $190^{\circ} \mathrm{C} て$ 測定した。

（5）密度 ASTM D 1505-85に規定されてい る密度勾配管法により測定した。PE，XLPEの密度 は密度測定までの熱履歴により変化するので，〈2・1〉 節で述べたように架橋の有無にかかわらず，同一の熱 履歴を与えた試料を作成し測定した。

（6）引張り特性 JIS K 7113-1981 に準拠して 引張り破断強さ，破断伸びを測定した。また，10\%伸 長モジュラスからヤング率も求めた。測定怯恒温槽付 き引張り試験機により, 室温 $90^{\circ} \mathrm{C}, 120^{\circ} \mathrm{C}$ で行った。

（7）転移温度測定 JIS K 7121-1987 に準拠 し，示差走查熱量計を用い相転移温度を測定した。本 実験で測定した相転移温度は，昇温時仁認められる結 晶融解温度 $\left(T_{p m}\right)$ と, 高温からの冷却時に生じる再結 晶温度 $\left(T_{p c}\right)$ である。

（8）絶緑破壊強度絶緑破壊強度の測定は図 2 に示すりセス状シートサンプルにより行った。りセス

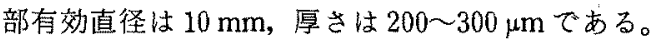
XLPEの場合, 架橋剂分解物の影響を避けるため, $50^{\circ} \mathrm{C}$ に残留分解物を減圧除去したものを試験に用い た。試料りセス部の上下面に銀ペイントを塗布し電極 を形成した。破壊試験はシリコーン油中で $90^{\circ} \mathrm{C}$ 扔よ び $120^{\circ} \mathrm{Cで}$ 行い， $\mathrm{AC}$ (昇压速度: $1 \mathrm{kV} /$ 分) および Impulse $(1 \times 40 \mu \mathrm{s}, 5 \mathrm{kV}$ ステップ, 各ステップ 3 回 印加）の両特性を評価した。

\section{3. 結果と考察}

〈3・1〉 ベース PEの諸物性＼cjkstart各種ベース PEの 物性評価結果を表 3 に示す。また，分子量分布測定結 果を図 3 に揭げる。電気絶縁用 PE は試料による多少 の違いはあるが, 分子量 1,000 程度から数百万程度ま
での幅広い分子量分布を示すことがわかる。分子量分 布を考虑した表現方法として数平均分子量 $\left(M_{n}\right)$, 質 量平均分子量 $\left(M_{w}\right)$, 分散度がよく使用されて枋り, 下式で定義される。

$$
\begin{aligned}
& M_{n}=\Sigma M_{i} N_{i} / \Sigma N_{i} \cdots \cdots \\
& M_{w}=\Sigma M_{i}{ }^{2} N_{i} / \Sigma M_{i} N_{i} \\
& \text { 分散度 }=M_{w} / M_{n} \cdots \cdots
\end{aligned}
$$

表 3 もこの方法により分子墨を表してある。表中, $M_{n}$ は 3 試料間に大きな相違はないが， $M_{w}$ および分 散度 $\left(M_{w} / M_{n}\right)$ にかなり大きな違いがみられる。すな わち, 試料 $A$ は $M_{w}$ および分散度が 3 者中最も大き く, 試料 $B$ は $M_{w}$ および分散度が最小, 試料 $C$ が中 間になる。これらの銘柄による分子量の違いは PE 重 合装置の違いや材料設咕偉いによるものと考えられ る。

相転移温度の測定結果では，密度の大きいPEほど 結晶融解ピーク温度 $T_{p m}$ が高い傾向が見られた。再 結晶化ピーク温度 $T_{p c}$ は試料間での差が小さいので 明確ではないものの，密度との間に同様の傎向がある ようである。文献(16)によると，PE 結晶の融点は結 晶厚さの関数で，次式で与えられる。

$$
T_{m}=T_{m 0}(1-2 \sigma / L \Delta H)
$$

ただし， $T_{m}$ : 結晶厚さ $L$ の $\mathrm{PE}$ の融点, $T_{m 0}$ : 平衡状態におりる融点, $\sigma:$ 結晶折り たたみ鎖の表面自由エネルギー, $\Delta H:$ 融解 熱

結晶厚さLは結晶化度の上昇に伴い増大するので， 結晶化度の增大に伴い融点, すなわち, 結晶融解温度 は上昇することになる。密度は結晶性の程度を示すも のであることから本測定結果は妥当なものであると結 論される。この結果は表 3 中, 赤外吸光度法で求めた 結晶化度の順序にもよく対応している。結晶化度の值 は通常のX線回折法などで求められる值に比較し約 $20 \%$ 高い值を示しているが，赤外法による結晶化度は 一般に高い值を与えるとの報告(17)があり，本測定も 同様の結果である。

表 3 亿浾外吸収スペクトルから求めた PE 試料中 に存在する化学構造も示してある。3種のPEに認め られる化学構造は量の多少はあるが共通している。一 般にLDPE は多くの分岐を有するが，本測定でも分 岐末端の化学構造として，メチル基 $\left(\mathrm{CH} \mathrm{3}_{3}\right)$ ，イソプ ロピル基 $\left[\left(\mathrm{CH}_{3}\right)_{2}=\mathrm{CH}-\right]$, ビニル基 $\left(\mathrm{CH}_{2}=\mathrm{CH}-\right]$, ビニリデン基 $\left[\mathrm{CH}_{2}=\mathrm{C}<\right]$, 第 3 アルコール基 ( $\left.\mathrm{HO}(\mathrm{R}) \mathrm{C}\left(\mathrm{R}^{\prime}\right)-\right]$, メチ儿分岐 $\left[-\left(\mathrm{CH}_{2}\right)-\mathrm{CH}\left(\mathrm{CH}_{3}\right)-\right.$ $\mathrm{CH}_{2}$-)などが認められた。このほかに $\mathrm{PE}$ 分子鎖中の 
表 3 ベース PE の評価結果

Table 3. Characterization results of PE.

\begin{tabular}{|c|c|c|c|c|c|c|c|}
\hline \multirow{2}{*}{ 植船i } & \multicolumn{3}{|c|}{ 分 $74\left(\times 10^{3}\right)$} & \multirow{2}{*}{$\begin{array}{c}\text { MFR } \\
(s / 10 \mathrm{~min})\end{array}$} & \multirow{2}{*}{$\begin{array}{l}\text { (sili: } \\
\left(\mathrm{g} / \mathrm{cm}^{3}\right)\end{array}$} & \multicolumn{2}{|c|}{ 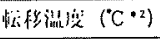 } \\
\hline & $\bar{M} n$ & $\bar{M} w$ & $\bar{M}_{w} / \bar{M}_{11}$ & & & $T_{\text {min }}$ & $T_{\mu, c}$ \\
\hline A & 15.0 & 97.0 & 6.49 & 1.02 & 0.9176 & 108 & 97 \\
\hline B & 17.3 & 67.1 & 3.87 & $1: 17$ & 0.9225 & 111 & 98 \\
\hline C & 14.7 & 87.0 & 5.90 & 1.22 & 0.9210 & 110 & 98 \\
\hline
\end{tabular}

\begin{tabular}{|c|c|c|c|c|c|c|c|c|c|}
\hline \multirow[b]{2}{*}{ 耗類 } & \multicolumn{8}{|c|}{ 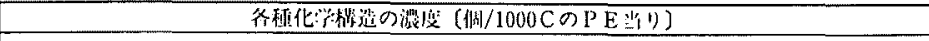 } & \multirow[b]{2}{*}{ 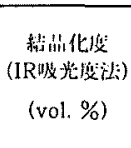 } \\
\hline & $\mid \begin{array}{c}\text { アルコール } \\
\text { 性OH }\end{array}$ & $\begin{array}{c}\text { 全 } \mathrm{CH}_{3} \\
\text { 基 }\end{array}$ & $\begin{array}{l}\mathrm{CH}_{3} \\
-\mathrm{CH}^{-} \\
\text {分忮 }\end{array}$ & $\begin{array}{l}\mathrm{CH}_{3} \\
\mathrm{CH}- \\
\mathrm{CH}_{3}\end{array}$ & $\begin{array}{c}\mathrm{CH}_{2}=\mathrm{CH}^{-} \\
\text {基 }\end{array}$ & $\begin{array}{c}\mathrm{CH}_{2}=\mathrm{C}<1 \\
\text { 基 }\end{array}$ & $\begin{array}{c}-\mathrm{CH}=\mathrm{CH}^{-} \\
\text {基 }\end{array}$ & 食分岐 $* 1$ & \\
\hline A & 0.46 & 24.6 & 3.8 & 1.3 & 0.19 & 0.53 & 0.11 & 23.7 & 61 \\
\hline B & 0.46 & 22.0 & 5.1 & 1.6 & 0.36 & 0.27 & 0.08 & 20.7 & 66 \\
\hline $\mathrm{C}$ & 0.47 & 22.2 & 2.8 & 1.5 & 0.20 & 0.41 & 0.08 & 20.9 & 64 \\
\hline
\end{tabular}

*1： 全分畦=（全メチル基）－（ジメチル基）－(アルコール基）+(ビニル基）＋(ビニリデン基）+（トランスビニレン基）

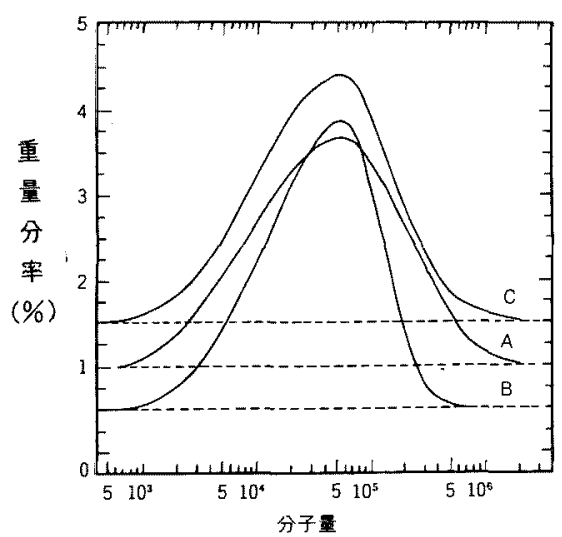

园 3 ベース PEの分子量分有

Fig. 3. Molecular weight distribution of PE.

構造としてトランスビニレン基 (trans- $\mathrm{CH}=\mathrm{CH}-$ ) が 認めら狄た。表中の全分岐として示した值は，全メ子 ル基数からメチル基を有する末端化学基，アルコール 基（メチル基を含有する）を差し引いて各種末端基数 を総計したものである。表中の值は炭素(C) 1,000 個 当たりの值であるが，一方，1,000 Cの $\mathrm{PE} の$ 式量は 14,000 であり,この值は試料 $\mathrm{PE}$ の数平均分子量 $M_{n}$ にほほ等しい值である。従って, 表中の各化学棈造の 数値はPE 1 分子あたりの平均個数とみなすことがで きる。 3 試料中の化学構造成分に大きな差巽はないが, 試料 $A ， C$ に比較し，試料 $B$ がイソプロピル基およ びビニリデン基の濃度がやや多いといえよう。こうし た微量な構造成分の違いが物性值にどのように影響す

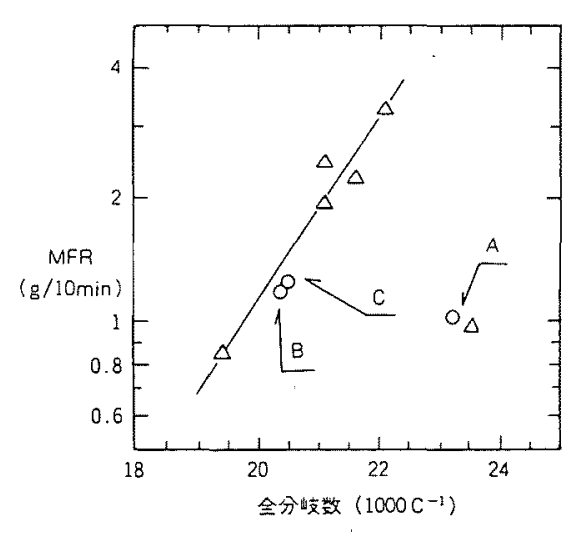

図 4 MFR と全分岥数の関係

Fig. 4. Relation between MFR and $n$-branch of PE.

るかについては後項で詳述する。

〈3.2〉ベースPEにおける物性相互の関係

表 3 に示す 3 試料扣よび参考試料 6 点の赤外分析結 果と物性値との関係を比較検討した。図 4 はMFR と 全分肢数の関係をプロットしたものである。図から相 関関係のあるグループとこれからはずれる他のグルー プに大別される。相関関係があるとみなせるグループ は $M_{w}$ が $60,000 \sim 70,000$ の $\mathrm{PE}$ でり，これからはず れる右下の 2 点は $M_{w}$ が 100,000 110,000 程度の $\mathrm{PE}$ である。この結果は $M_{w}$ が同等の場合，分岐数が多い ほどMFRも大きくなる傾向のあることを示してい る。試料 $A, B, C$ を比較すると， 3 者とも MFR は約 1 の同程度の大きさであるが，重合条件により 


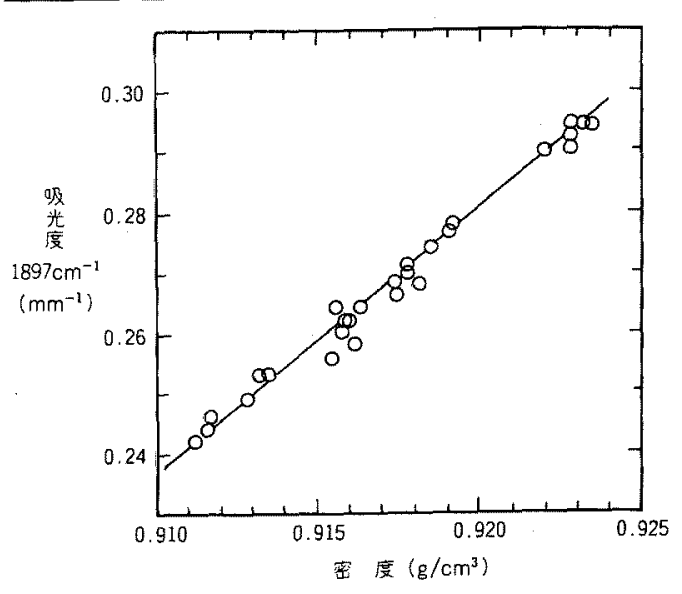

図 5 結晶バンド吸光度と密度の関係

Fig. 5. Relation between absorbancy of crystal band and density.

$A$ のうに分岐数を多く，あるいは $B, C$ あうに 分岐数を制限することにより MFR 特性を設計できる ことが示された。

以上の結果から，PEのMFR特性は分子量のみで なく分岐数によっても調整可能であることが示され to

図 5 に PEよよ゙ XLPEの赤外吸収スペクトル中 の結晶バンド $\left(1,897 \mathrm{~cm}^{-1}\right)$ の吸光度と密度の関係を示 す。密度と結晶バンドの吸光度に密接な相関が認めら れた。この結果は, 密度が結晶化度の一次の関数であ ることから予湘される結果であり，架橋によってもそ の関係が保たれていることを示している。

〈3・3〉架橋による構造変化 有機過酸化物によ るPEの架橋は加熱により過酸化物がラジカルを発生 し,このラジカルが PEから水菜を引き抜きPEをラ ジカル化し, 生じたPEラジカルどうしの結合により 架橋が生じると理解されているが，架橋反応で゙のよ うな化学変化が起き, ベースPEの化学構造にどのよ うな変化が生じているのかを詳しく把握することが, PE およびXLPEを正しく理解するうえで重要である と考えられる。

比較試料 3 種执よび参考試料 6 種の PEを DCPで 架橋した XLPEにつき赤外吸収スペタトルを測定し， 化学構造基の種類, 濃度を調べた結果, 図6に示すよ うに，XLPEではベース PEで認められたすべての化 学構造基が認められ，図 1 に示寸ように，新たにジメ チル分岐の生成が認められた。化学構造基の種類によ り架橋前後で増減が観察され, 表 4 に示す 3 グループ に大別される。また，架橋剤であるDCP量を增加さ

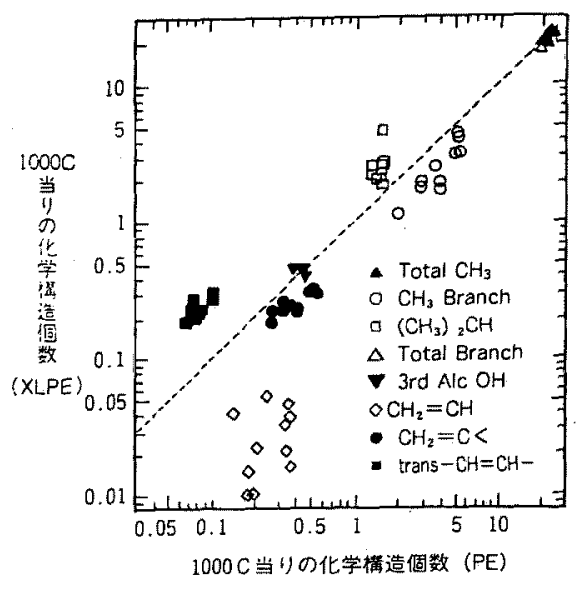

図 6 化学構造濃度のPE とXLPE 相関 プロット

Fig. 6. Corelation plot between chemical component numbers in $\mathrm{PE}$ and those number in XLPE.

表 4 架橋による化学構造基の変化

Table 4. Changes of chemical component by crosslinking.

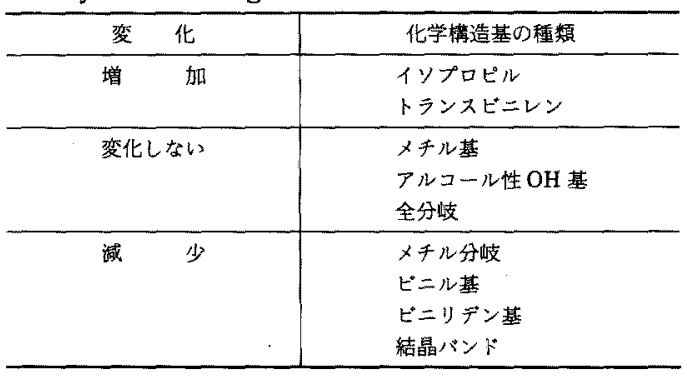

せて架橋した場合の挙動は，トランスビニレン基のい っそうの増加とビニりデン基のいっそうの減少であっ た。XLPEに新たに発生したジメチル分岐, 架橋に より増加しているイソプロピルは目立った変化を示さ なかった。

架橋度 (ゲル分率) と化学構造基の変化との相関を 調查した結果, 最も強い相関を示したのは，どニル基 およびビニリデン基とゲル分率の関係であった。その 結果を図 7 に示す。架橋度の上昇に伴うビニリデ基 の隇少理由は明確ではないが，何らかの形で架橋に関 与しているものと推定される。図 7 は DCP 量が $1.8 \%$ 場合の結果であるが，比較試料 3 種につき DCP 量を変量した場合のゲル分率の変化は図 80 と おりであった。試料 $A, C$ に比較し試料 $B$ は架橋し やすいPEであるといえる。試料 $B$ は $A, C$ に比較 
し，ビニル基濃度が高い PEであり，ビニル基が架橋 開始点になっていると考えられるが，ビニル基濃度を 0に外挿した点におけるゲル分率は 0 よりも大きく， ビニル基以外に架橋開始点のあることを示唆してい る。一方，PE分子すへてが架橋し，全体が一つの

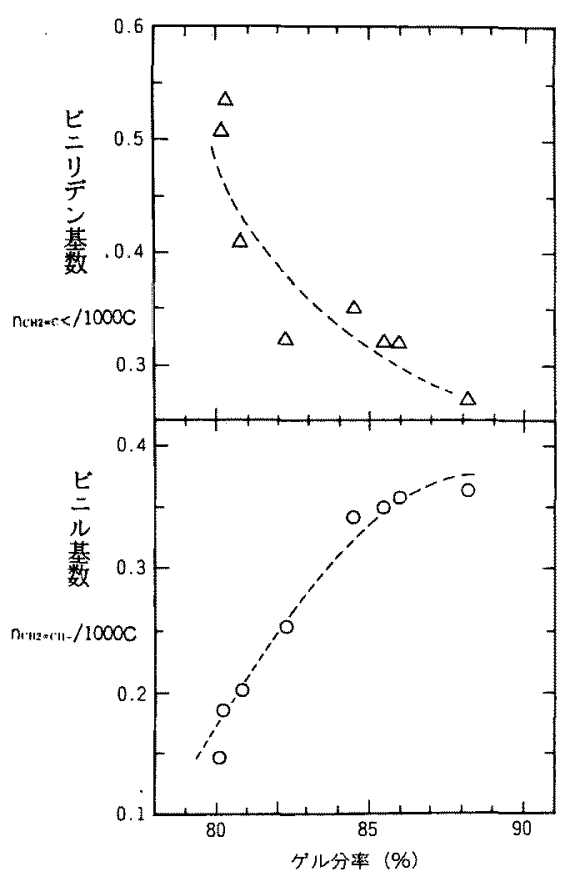

园 7 ゲル分率と $n_{\mathrm{CH}_{2}=\mathrm{CH}-}$ と $n_{\mathrm{CH}_{2}=\mathrm{C}<}$ の関係

Fig. 7. Relation between gel content and $n_{\mathrm{CH}_{2}=\mathrm{CH}-}$ or $n_{\mathrm{CH}_{2}=\mathrm{C}<\text {. }}$

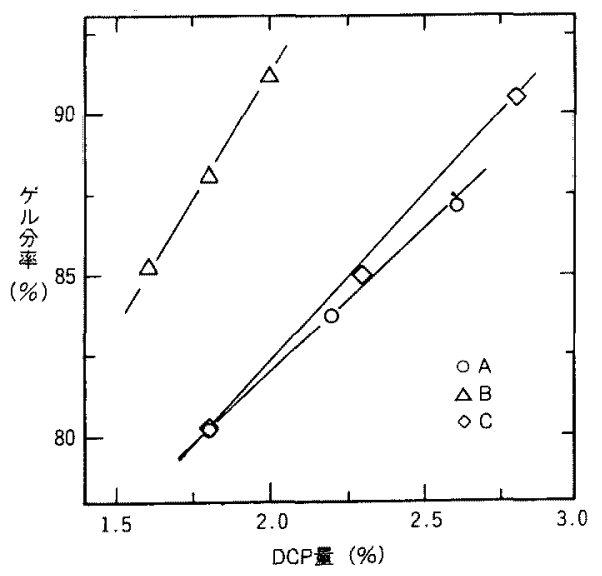

図 8 DCP変量によるゲル分率の変化

Fig. 8. Changes of gel content by DCP concentration.
XLPE 分子となるために必要な分子閪架橋点数は, もとのPE 1 分子中に最低 2 個あればよいと考えられ る。実際，XLPEの架橋点間平均分子量は，ゲル分 率 $80 \%$ 程度の場合， $M_{n}$ にほぽ匹敵するとの報告(18) があり，今回の測定でわかるように，ビニル基は PE 1 分子中に 1 個末満しか含まれておらず, ビニル 基がすべての架橋点を形成しているのではなく，ビニ ル基のような二重結合からの架橋反応と, $-\mathrm{CH}_{2}{ }^{-}$, あ るいは $-\mathrm{C}(\mathrm{R}) \mathrm{H}-$ からの水素引き拔き反応の両者によ り架橋が生じていると推定される。

〈3・4〉 XLPE $の$ 諸物性 PEは半結晶性高分子 であり, 雲囲気温度により結晶化度が変化する。この ことが PEの機械的特性に大きく影響していることは よく知られているが，XLPEにおいては融点以上の 雲囲気においても，架橋網目構造をもつ弾性体として の特性をもつため，未架橋 PEと異なった種々の特性 宗方。

図 9 に種々の架橋度をもつXLPEの引張り特性を 室温, 融点近傍 $\left(90^{\circ} \mathrm{C}\right)$, 融点以上 $\left(120^{\circ} \mathrm{C}\right)$ で測定した

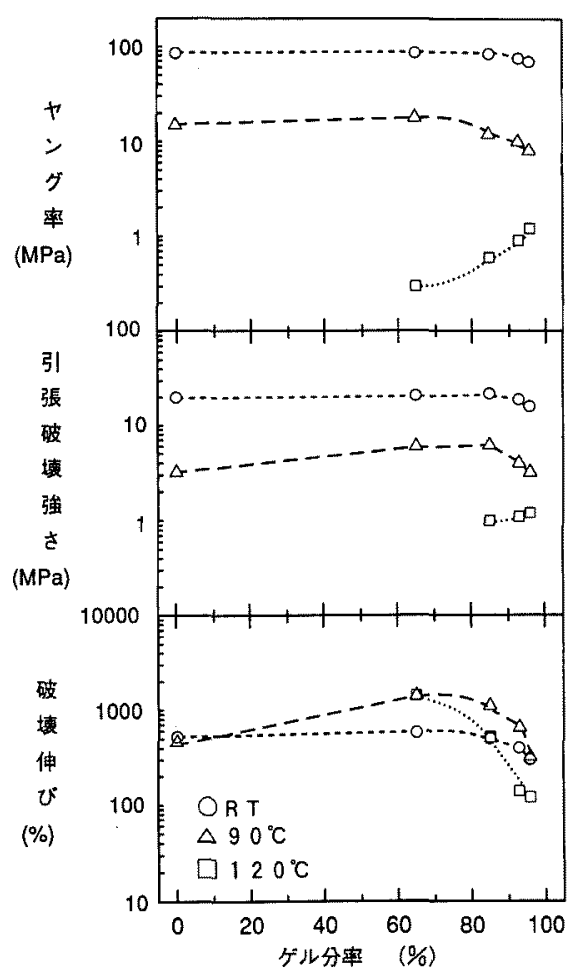

図 9 ゲル分率と引張り特性の関係 Fig. 9. Relations between tensile properties and gel content. 
結果を示す。ヤング率は室温では架橋度によらず，ほ 䛱一定值を示し，高ゲル域でわずかに低下の傾向を示 す。 $120^{\circ} \mathrm{C} て の$ 值は架橋度が高くなるにつれ増加の傾 向を示す。9 $90^{\circ} \mathrm{Cでは}$ 両者の中間の特性を示していると

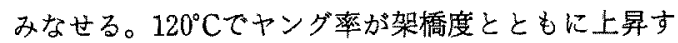
るのは, 結晶が融解して存在しない融点以上の温度領 域における弾性は XLPE 架橋網目構造体に基づくエ ントロピー弾性であることを考学れば，架橋度の上昇 は架橋密度を高め, 弾性率を上昇させることから理解 できる。室温において高架橋領域でわずかなヤング率 の低下を示す理由は, 架橋による結晶化度の減少によ ると考えられる。 $90^{\circ} \mathrm{C}$ は両者の中間の特性を示してい ると考えられる。引張り特性もヤング率と類似の挙動 を示している。この場合, $120^{\circ} \mathrm{C}$ 㭁ける引張り強さ の架橋度依存性はヤング率の場合ほど影著でない。破 壊伸びはゲル分率 60～ $80 \%$ で最大值を示し，架橋度 が極端に高い領域で，かつ温度の高い狅ど伸びの低下

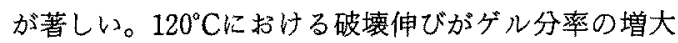
とともに急激に低下する現象は架橋網目密度が高くな った影響として理解できる。

次に, 架橋度と密度, 融点の関係を調べた結果を図 10 に示す。架橋により密度, 融点が変化することは 知られている ${ }^{(19)(20)}$ が, 詳細に調べると密度と融点の

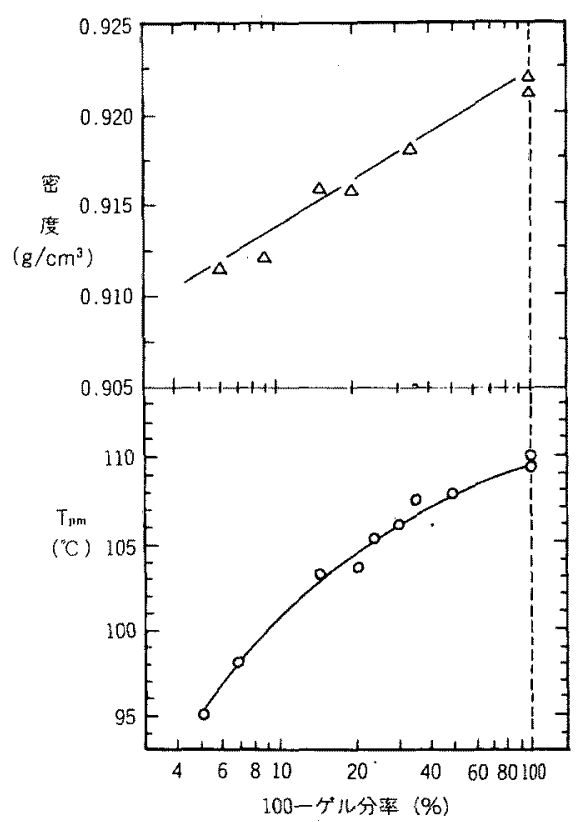

図 10 ゲル分率による密度と $T_{p m}$ の変化

Fig. 10. Changes of density and $T_{p m}$ by gel content.
ゲル分率に対する変化は暴なっていることが明らかと なった。密度はゲル分率に対しほほ直線的に変化する が，融点の変化は直線的でなく非架橋PEの融点に漸 近する傾向を示した。ゲル分率を $\log (1$ ゲル分率)の パラメータに変換すると $T_{p m}$ と直接的な関係になる との報告(19) があり，著者らの害験結果とは異なった 傾向を示している。しかし, PE 結晶の融点は結晶厚 さの関数であって，功結晶化度は結晶厚さ $L$ の一 次関数であることから，前揭の（5)式に示すとおり， $T_{m}$ が結晶化度の增加に対し直接的な変化を示さず, $T_{m 0}$ に漸近する傾向を示すほうが妥当であると考えら れる。この結果は, XLPEにおいても PE と同様の結 晶学的取扱いが成立することを示すものである。ま た，XLPE絶緑ケーブルを考えた場合，上述の機械 的特性とのバランスとも関連するが，ゲル分率が $90 \%$ を超之ると融点は $100^{\circ} \mathrm{C}$ 以下となり，ケープル使 用温度から考えて適切な架橋度の選定が必要であるこ とも示された。

〈3.5〉 XLPEの絶縁破壊特性架橋により PE の高温での絶緑破壇特性低下が抑制されることは知ら れている(21) が, 著者らは架橋の程度により, 特性が どのように変化するのかについて詳しく測定した。結

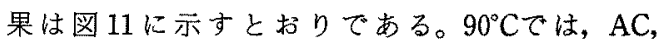

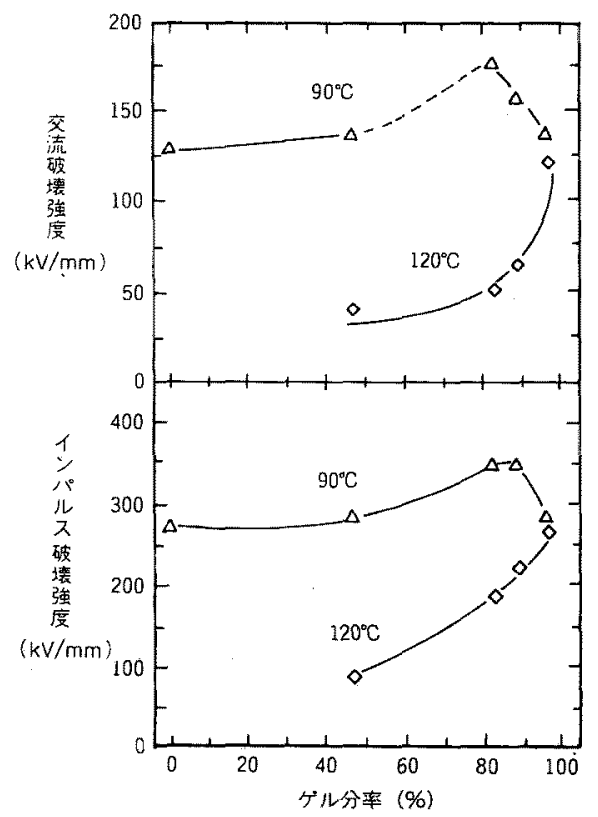

図 11 ゲル分率と絶緑破壊強度の関保 Fig. 11. Relations between dielectric strength and gel content. 
Imp.ともにゲル分率 $80 \%$ 近傍に極大が見られる。通 常, CV ケーブルのゲル分率は 80 数\%であるが, 絶緑 破壊特性からも最適の値であることが示された。 $120^{\circ} \mathrm{C}$ においてはゲル分率の增大とともに絶緑破壊強 度は向上する。高分子材料の絶縁破壊機構は複雑であ り，単一の機構で破壊現象が生じているとは考えられ ない。著者らはこうした事実を考慮したうえで, 本実験 結果を最も満足する絶緑破壊機構の考察を試みた。室 温を含む高温域での高分子材料の絶縁破壊は Frorich の非鼠䁈破壊や，自由体積破壊などによるとの考光 方があるが，著者らが以前検討した結果では, 結晶性 高分子材料においても融点あるいは軟化点近傍以上の 温度領域における絶緑破壤強度 $E_{B D}$ は, 材料のヤン グ率 $(Y)$ に依存する電気機械的破壊が支配的であると の結論を得た(22)。そこで, 今実験で得られた結果に ついての支配的な破壊機構を推定する目的で, 図 11 に格いて, 融点以上の領域 $\left(120^{\circ} \mathrm{C}\right)$ のデータにつき電 気機械的破壊成立の可否を確認した。結果は図 12 の と朽りで，AC，Imp.ともにほぼ勾配 $1 / 2$ の直線に従 った特性を示した。従って, 本実験におけるXLPE の融点以上の高温域での絶縁破壊はヤング率の $1 / 2$ 乗 に比例する電気機械的破壊が支配的であると結論され る。一方, $90^{\circ} \mathrm{C} に$ 扔て, 絶緑破壊強度がゲル分率が 80\%近傍で最大值を示す理由ははっきりしないが，こ の温度域では架橋度が高くなるにつれ架橋網目による 非晶部の分子鎖補強が破壞特性向上に寄与し， あまり に架橋度が高くなると結晶化度の低下をまねきゴム的

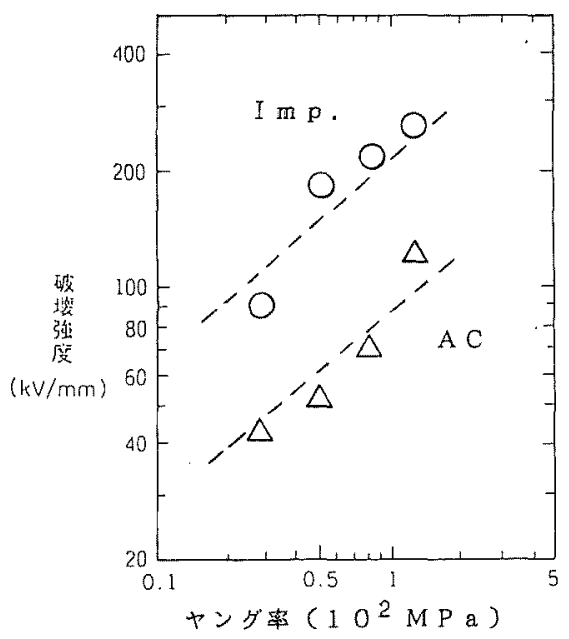

図 12 絶縁破壊強度とヤング率の関係

Fig. 12. Relation between dielectric strength and Young's Modulus.
になるため，破猿值が低下していくものと推定され る。しかし，本実験に扔引 AC 破壊注破壊までの時 間が数分間という短時間破壊であり, 部分放電劣化な どを伴う長時間破壊とは破壊機構が異なることはもち ろんであり, 架橋網目構造が長時間放電劣化などに与 える影響については今後の検討課題であろう。また， ケーブルのような厚肉絶縁体については, 更に複雑な 要因が関係することも考えられる。

\section{4.むすび}

XLPE絶縁電力ケーブル用ベース PEおよび XLPEの諸物性を評価し,次のことが明らかとなった。 ベース PEの MFR は同一の值であってもその分子 量分布は同一ではない。PEの質量平均分子量が大き くなると MFR は小さな値を示すが，質量平均分子量 が同一の場合，分㞳数が多いほど MFR は大きくなる 傾向を示す。

ベース PEには炭素 1,000 個当たり約 20 個程度の 分岐があり，メチル分岥がビニリデン基などの短鎖分 岐抒よび分岐末端の化学構造基としてメチル基，イソ プロピル基,第 3 アルコール基㧍よびビニル基, 不飽和 化学構造であるビニレン基の存在が認められた。これ らの化学構造基の濃度は銘柄間でかなり相違している。

DCPによる架橋反応に招いては，様々な反応が生 じて扔り, 架橋により発生, 増加, 減少, あまり変化 しない化学構造基のあることが明らかとなった。ビ二 ル基扔よびビニリデン基が架橋反応と密接に関係し， ビニル基の増加は架橋度を向上させるが，一重結合か らの水素引き抜き反応も架橋に関与していると推定さ れた。

XLPEの機械的特性と架橋度との関係を測定した 結果, 架橋による結晶性の低下および架橋網目形成が XLPE の物性を支配していることを示した。密度, 結晶融解挙動についての検討結果から, 結晶厚さに依 存する結晶融解温度 $\left(T_{p m}\right)$ は架橋度とともに低下する ことが示された。

XLPEの絶緑破壊特性は架橋度により異なり，ケ

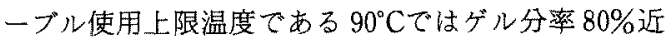
傍で絶縁破壊特性が最も優れていることが示された。 また, 融点以上の特性は架橋度の増加に伴い上昇する ことが示され，この温度領域に㧍ける破壊は主として ヤング率に支配される電気機械的破壊によることも推 定された。

以上の結果は今後の絶緑材料開発に有益な情報を提 供するものと考えられる。

(平成 4 年 10 月 20 日受付, 同 5 年 5 月 10 日再受付) 


\section{文 献}

（1）神永，他：「ポリエチレンの結晶構造と電気特性(その 3$) 」 ，$ 第 19 回電気絶縁材料シンポジウム, VII-2（昭 61）

（2）長尾, 他：「高温領域にるけるポリエチレンフィルムの交流 絶縁破壊」, 電気学会絶縁材料研資, EIM-90-67 (平 2)

（3）山北：「フレンドボリマーの高次構造と絶縁破塤について」, 同上, EIM-90-77 (平 2)

（4）穂積, 他：「ポリエチンンの高次構造と電気トリー発生現 象」, 電学論 A, 108, 535 (昭 63-12)

(5) T. Niwa, et al.: "Morphological Studies of Water Tree in Polyolefin", IEEE International Symposium on Electrical Insulation p. 321 (1988)

(6) R. Ross, et al. : "The Hddrophilic Nature of Watertrees", ibid., p. 169 (1990)

（7）宮下・加藤：「XLPE の架橋メカニスムと DCP 分解残置の 举動, 三菱電線時報, No.77, 39 (平元)

（8）辻本, 他：「架橋ポリエチレンのキャラクタリゼーションに ついて」, 同上, No. 80, 49 (平 2)

（9） L. J. Bellamy (稲本・竹内訳）：有機基の赤外吸収（昭 46）広 川書店

（10）堀口：赤外吸光図説総覧（昭 48）三共出版

(11) The Sadtler Handbook of Infrared Spectra (1978) Sadtler Res. Lab.

(12) T. Usami \& S. Takayama : "Identification of Branches in Low Density Polyethylens by Fourier Transfom Infrared Spectroscopy", Polymer J., 16, 731 (1984)

（13）白山：「高分子の Characterization と物性」, 化学增刊, 43, 131 (昭 45)

(14) M. A. McRae \& W. F. Madama : "Infrared Spectroscopic Studies on Polyethylene, 3", Macromol. Chem., 177, 461 (1976)

（15）寺西・菅原：「赤外線吸収におけるポリエチレンの分析と結 晶性に開する検討」, 高分子化学, 23, 512 (昭 41)

（16）平井, 他：「ポリエチレン単結晶の熱処理による厚化, 第 1 報」, 高分子化学, 18, No. 189, 33 (昭 36)

(17) 岡・山形：ポリエチレン樹脂（昭 46）日刊工業新聞社

（18）島居・一色，他：「架橋ポリエチレンの特性と耐熱性ポリエ チレン電線への応用に関する研究」, 藤倉電線技報, No. 20, 55 (昭 36)

(19) M. Duval \& H. St-Onge: "HPLC and DSC Analysis of Crosslinked PE from HV Cables", IEEE Trans. Elect. Insulation, 14, No. 5, 264 (1979)

（20）新田・東村：「融点近傍における PE，XLPEのトリー発生 と高次構造の関係」, 第 12 回電気絶緑材料シンポジウム, I-6 (昭 54)

（21）犬石・家田, 他：誘電体現象論, p. 266, 電気学会

(22) 高橋・丹羽, 他：「結晶性ポリオレフィンの固体構造と絶緑 破壊特性」, 藤倉電線技報, No. 69, 59（昭60）

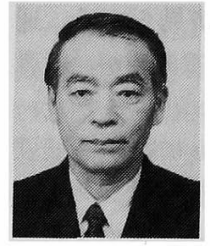

中 山 四 郎 (正員)

昭和 10 年 6 月 11 日生。 29 年 4 月藤 倉電線(株) (現, フジクラ)入社。35 年 3 月東京理科大学 II 部化学科卒業。現 在, (株) フジクラ基盤材料研究所主管研 究員。主として, 絶縁材料, 機能性材料の開発に従事。応 用物理学会会員。

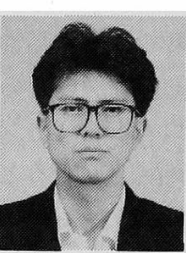

学会会員。

\section{小 林 一 治 (非会員)}

昭和 38 年 2 月 24 日生。 57 年 3 月新 潟大学大学院工学研究科修士課程修了。 同年 4 月藤倉電線 (株) (現，フジクラ)入 社。絶縁材料の分析に従事。日本分析化

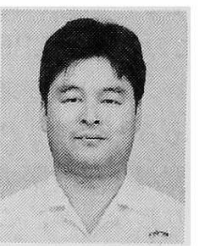

\section{中 司徹（非会員）}

昭和 33 年 4 月 8 日生。平成元年 3 月 広島大学大学院理学研究科博士課程修 了。同年 4 月藤倉電線 (株) (現，フジク ラ) 入社。主として, 超高圧電力ケーブ ル絶緣材料の開発に従事。理学博士。

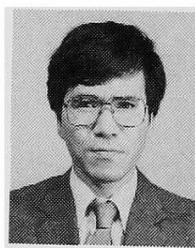

\section{高 橋＼cjkstart享（正員）}

昭和 23 年 8 月 12 日生。 49 年 3 月北 海道大学大学院工学研究科修士課程修 了。同年 4 月藤倉電線 (株) (現, フジク ラ) 入社。現在, 同社基盤材料研究所主 管研究員。主として, 超高圧電力ケーブル絶縁材料の開発 に従事。

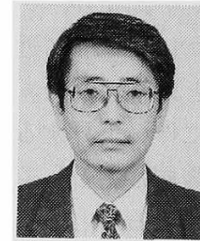

\section{丹 羽 利 夫 (正員)}

昭和 18 年 12 月 21 日生。 43 年 3 月広 島大学大学院理学研究科修士課程修了。 同年 4 月藤倉電線 (株) (現，フジクラ) 入社。現在，同社基盤材料研究所次長。 主として, 超高圧電力ケーブル絶縁材料の開発に従事。高 分子学会会員。

$\& \quad \& \quad \&$

